\title{
Review
}

\section{Novel and Future Treatment Options in Mesothelioma: A Systematic Review}

\author{
Danijela Štrbac ${ }^{1}\left(\mathbb{D}\right.$ and Vita Dolžan ${ }^{2, *(\mathbb{D})}$ \\ 1 Institute of Oncology, Zaloška 2, 1000 Ljubljana, Slovenia; dstrbac@onko-i.si \\ 2 Pharmacogenetics Laboratory, Institute of Biochemistry and Molecular Genetics, Faculty of Medicine, \\ University of Ljubljana, Vrazov trg 2, 1000 Ljubljana, Slovenia \\ * Correspondence: vita.dolzan@mf.uni-lj.si
}

check for updates

Citation: Štrbac, D.; Dolžan, V. Novel and Future Treatment Options in Mesothelioma: A Systematic Review. Int. J. Mol. Sci. 2022, 23, 1975. https://doi.org/10.3390/ ijms23041975

Academic Editors: Ioannis Kalomenidis and Magkouta Sophia

Received: 13 January 2022

Accepted: 3 February 2022

Published: 10 February 2022

Publisher's Note: MDPI stays neutral with regard to jurisdictional claims in published maps and institutional affiliations.

Copyright: (C) 2022 by the authors. Licensee MDPI, Basel, Switzerland. This article is an open access article distributed under the terms and conditions of the Creative Commons Attribution (CC BY) license (https:// creativecommons.org/licenses/by/ $4.0 /)$.

\begin{abstract}
Mesothelioma is a rare tumor, frequently associated with asbestos exposure, arising from pleura and peritoneum. Traditionally, diagnosis and treatment have been difficult in a clinical setting. The treatment is based on a trimodal approach involving surgery, chemotherapy, and radiotherapy. The introduction of chemotherapy improved the overall survival. However, the regimen of pemetrexed/cisplatin doublet has not been changed as a standard treatment since 2004 Novel combinations of ipilimumab and nivolumab have only been approved for clinical use in late 2020. The aim of this review was to systematically summarize findings on novel treatment options in mesothelioma. We searched available medical databases online, such as PubMed and Clinicaltrials.gov, to systematically review the literature on novel approaches in immunotherapy, vaccines, and Chimeric Antigen Receptor (CAR)-T cell therapy in mesothelioma. We manually screened 1127 articles on PubMed and 450 trials on ClinicalTrials.gov, and 24 papers and 12 clinical trials published in the last ten years were included in this review. Immunotherapy that was swiftly introduced to treat other thoracic malignancies was slow to reach desirable survival endpoints in mesothelioma, possibly due to limited patient numbers. Novel treatment approaches, such as CAR-T cell therapy, are being investigated. As the incidence of mesothelioma is still rising globally, novel treatment options based on a better understanding of the tumor microenvironment and the genetic drivers that modulate it are needed to support future precision-based therapies.
\end{abstract}

Keywords: mesothelioma; chemotherapy; immunotherapy; CAR-T cells; vaccine therapy; gene therapy

\section{Introduction}

Mesothelioma is a rare disease with over 30,000 new cases worldwide in 2020. The mortality of this disease was reported for over 26,000 patients, representing $45 \%$ of all new cases in Europe in 2020 [1]. The incidence of mesothelioma has risen in recent decades due to asbestos exposure. The latency period from asbestos exposure to disease is over 25 years long [2,3]. However, there is problem of under-reporting in middle and lower income countries, where the rise of mesothelioma incidence is higher than in some developed countries [4].

The pathogenesis of mesothelioma is complex due to the interplay of environmental and genetic factors influencing the inflammatory tumor microenvironment. As recently reviewed by Hiltbrunner et al., mesothelial cells exposed to asbestos fibers secrete CC chemokine ligand 2 (CCL2), which attracts macrophages. Reactive-oxygen species induced DNA damage, and mutations in mesothelial cells lead to necrotic cell death and the production and release of damage-associated molecular patterns (DAMPs), including High Mobility Group Box 1 protein (HMGB1). The binding of HMGB1 to mesothelial cells enhances their proliferation and migration capacity. Furthermore, the recruitment of macrophages leads to phagocytosis of asbestos fibers, resulting in the secretion of proinflammatory mediators, such as TNF- $\alpha$, that support carcinogenesis and cancer cells 
survival. Asbestos fibers and DAMPs also activate inflammasome that activates caspase 1, which activates pro-IL-1 $\beta$ into IL- $1 \beta$. TNF- $\alpha$ released by macrophages activates the NF$\mathrm{KB}$ signaling pathway in mesothelial cells and supports their survival when exposed to asbestos. Therefore, TNF- $\alpha$ and IL-1 $\beta$ are important players mediating mesothelioma malignant transformation and progression [5].

Besides the crucial role of the inflammatory microenvironment in mesothelioma development and progression, genetic and epigenetic mechanisms have an important role. Oncogene activating mutations are rare, but the loss of function mutations in tumor suppressor genes have a prominent role in mesothelioma. Two of the most frequently mutated tumor suppressor genes in mesothelioma are neurofibromatosis type 2 (NF2) and BRCA1associated protein-1 (BAP1) genes. NF2 encodes Merlin, which regulates multiple signaling pathways, including the Hippo pathway, and is a critical regulator of contact-dependent inhibition of proliferation and cell growth. BAP1 encodes a nuclear ubiquitin C-terminal hydrolase, one of several classes of deubiquitinating enzymes. BAP1 interacts with several proteins, such as BRCA1 and BARD1, which form a tumor suppressor heterodimeric complex. It also interacts with histone-modifying complexes, such as the Polycomb group repressive deubiquitinase complex.

Furthermore, alterations in DNA methylation patterns have been observed in mesothelioma, especially in E-cadherin, fragile histidine triad, retinoic acid receptor- $\beta$, and wnt inhibitory factor-1. Dysregulation of microRNA (miRNA) expression may also contribute to the development of mesothelioma. MiRNAs are short non-coding RNAs that regulate gene expression at the post-transcriptional level. Several miRNAs have been extensively investigated for their potential tumor suppressor role in mesothelioma or as a promising biomarker and possible anti-proliferative and anti-tumor activity. For example, overexpression of hsa-miR-29c* resulted in a significant decrease in proliferation and migration in mesothelioma cell lines. Therefore, overexpression of hsa-miR-29c* could impact a more favorable prognosis in epithelioid mesothelioma patients [5,6]. Furthermore, cell cycle regulation can influence the progression of mesothelioma. A mechanism of aberrant and homozygous deletion status of the p16CDKN2A gene can promote mesothelioma growth since $\mathrm{p} 16$ is a protein that slows cell division by slowing the progression of the cell cycle from $\mathrm{G} 1$ to $S$ phase [7-9].

Mesothelioma can be classified into two main types: pleural and peritoneal mesothelioma; however, there are also rare manifestations of mesothelioma in tunica albuginea of the testis. Histological classification divides mesothelioma into epitheloid, sarcomatoid, and biphasic, but different histological types may overlap [10]. The clinical presentation of mesothelioma can be late in advanced disease with pain, dry cough, weight loss, and fatigue. While asbestos exposure is the leading risk factor in developing mesothelioma, rare cases are genetically predisposed, such as in BAP1 mutations. Mesothelioma can be staged by tumor, node, metastasis (TNM) classification according to the latest eighth TNM classification edition [11]. Tumors involving the unilateral parietal pleura (T1NOM0) are grouped into stage IA. In contrast, tumors involving visceral pleura and/or mediastinal fat, solitary infusion of the chest wall, and no nodal involvement (T2,3N0M0) are staged as IB. Stage II involves T1,2 N1M0 tumors involving ipsilateral nodes. All the tumors of T3 (invasion of the fascia and solitary wall effusion) and ipsilateral positive nodes (N1) are staged as IIIA, and those involving contralateral nodes (N2) are staged as IIB. Stage IV applies to the tumors with massive thoracic wall involvement (T4) and any $\mathrm{N}$ or M stage [10-12].

The fact that mesothelioma is still classified as rare cancer has contributed to slow improvements in therapeutic options in the past decades. The trimodal approach to mesothelioma treatment was introduced in the 1990s by Sugarbaker et al. [13]. The trimodal approach includes surgery (pleurectomy or extrapleural pneumonectomy-EPP), adjuvant or neoadjuvant chemotherapy, and adjuvant radiation therapy. This treatment approach resulted in median survival of 20-29 months [14,15]. The most used chemotherapy doublet in this first-line treatment is a combination of pemetrexed and cisplatin or 
carboplatin. Combining gemcitabine and platinum-based chemotherapy agents can also be applied with similar results [16]. The trimodal approach is still the current standard of treatment in resectable stages of mesothelioma, according to the European Society for Medical Oncology (ESMO) and NCCN guidelines [17,18]. Patients with stages I-IIIa (pleural infiltration on one side of the thorax without invasion into the thoracic wall or other structures and nodes positive only on one side) may be eligible for surgery and neoadjuvant therapy. After radical surgery, radiation therapy with up to 54-60 Gy is delivered to the whole hemithorax with newer techniques, such as Intensity Modulated Radiation Therapy (IMRT) and Image-Guided Radiation Therapy (IGRT). Adjuvant radiotherapy should, however, be delivered with great caution in patients who did not receive extended pleural pneumonectomy (EPP) since the dose to the remaining lung and other organs at risk (heart, liver, stomach) can be toxic. An EORTC multicenter phase II trial recruited 59 mesothelioma patients with stages I-III that received neoadjuvant pemetrexed/cisplatin regimen, EPP, and postoperative radiation therapy of $54 \mathrm{~Gy}$ in 30 fractions [19]. The trial was concluded in 2010 but failed to reach the selected time frames, and the overall survival was 18.4 months. With the ongoing debate on the safety and efficacy of postoperative radiation treatment, a reverse approach was chosen in the newly published "SMART" trial. The patients received $25 \mathrm{~Gy}$ in five fractions preoperatively in that trial to reduce the disease burden. The trial's endpoint was distant recurrence which reached $63.3 \%$ at five years; however, the toxicity of this regimen has to be further evaluated [20]. Surgically operable patients can be candidates for hyperthermic intrathoracic chemotherapy (HITOCH). A systematic review by Zhao et al. suggested a more prolonged median survival of patients receiving HITOCH than patients without $\mathrm{HITOCH}$. The HITOCH treatment was proposed in a palliative setting, prolonging the recurrence-free interval in these patients [21].

However, the described trimodal approach is limited to resectable stages of mesothelioma. Advanced, stage IV mesothelioma treatment can be either standard chemotherapy or the best supportive care. Still, the introduction of immunotherapy in cancer treatment has been applied to mesothelioma as well. In combination, the standard chemotherapy regimen used in the neoadjuvant setting is pemetrexed/cisplatin or carboplatin. Immunotherapy with checkpoint inhibitors nivolumab or ipilimumab can be given in first-line systemic treatment or second-line if not given prior. Pembrolizumab is also an option in second-line treatment, according to the National Comprehensive Cancer Network (NCCN) [18]. The results of immunotherapy treatment in mesothelioma are promising, with a median survival of 11.8 months for nivolumab, but we are still waiting for the overall survival data [22]. Other chemotherapeutic treatments are used in a first-line, unresectable setting. These options are a combination of pemetrexed/cisplatin/bevacizumab, gemcitabine/cisplatin, vinorelbine or, nivolumab [23]. The current standard chemotherapy treatments in mesothelioma are summarized in Table 1.

Table 1. Current standard chemotherapy treatments in mesothelioma.

\begin{tabular}{|c|c|}
\hline Treatment Setting & Treatment Type \\
\hline neoadjuvant, preoperative & pemetrexed/cisplatin, carboplatin 4-6 cycles \\
\hline the first line, inoperable & $\begin{array}{c}\text { pemetrexed/cisplatin, carboplatin, the addition of bevacizumab optional, } 6 \text { cycles } \\
\text { nivolumab/ipilimumab until disease progression }\end{array}$ \\
\hline second and successive treatment & gemcitabine/cisplatin, pemetrexed single, vinorelbine weekly, nivolumab/ipilimumab \\
\hline \multicolumn{2}{|r|}{ Source: NCCN guidelines, Malignant pleural Mesothelioma v.2.2021 [18]. } \\
\hline & $\begin{array}{l}\text { Although novel approaches for mesothelioma treatment have been extensively in- } \\
\text { restigated, sixteen years have passed between the FDA approval of pemetrexed for } \\
\text { nesothelioma treatment and the approval of a new drug for mesothelioma, namely, } \\
\text { ivolumab/ipilimumab combination in first-line treatment [24]. Nevertheless, the usage } \\
\text { f standard chemotherapy-based regimens (e.g., cisplatin, gemcitabine) is not obsolete in } \\
\text { nesothelioma treatment since immunotherapy with checkpoint inhibitors (nivolumab, } \\
\text { embrolizumab) as standalone treatment is not the perfect solution }[25,26] \text {. Thus, a }\end{array}$ \\
\hline
\end{tabular}


combination approach of standard treatment options and novel strategies seems feasible in mesothelioma.

The aim of this review was to systematically summarize findings on novel treatment options in mesothelioma. We searched the available literature in the PubMed.gov and ClinicalTrials.gov databases $[27,28]$ to systematically review the literature on novel approaches in immunotherapy, vaccines, and Chimeric Antigen Receptor (CAR)-T cell therapy in mesothelioma. We manually screened 1127 articles on PubMed and 450 trials on ClinicalTrials.gov and the retrieved papers and clinical trials exploring novel treatment options in mesothelioma were stratified into four groups: (1) Immunotherapy with checkpoint inhibitors and novel combinations with chemotherapy; (2) Oncolytic viral and vaccine therapies; (3) CAR-T cell therapy in mesothelioma, and (4) Gene and genetic therapy principles in mesothelioma. Finally, 24 papers and 12 clinical trials published in the last ten years were included in this review. A flow diagram of the systematic search for studies on novel treatments and clinical trials in mesothelioma considered in this review is shown in Figure 1.

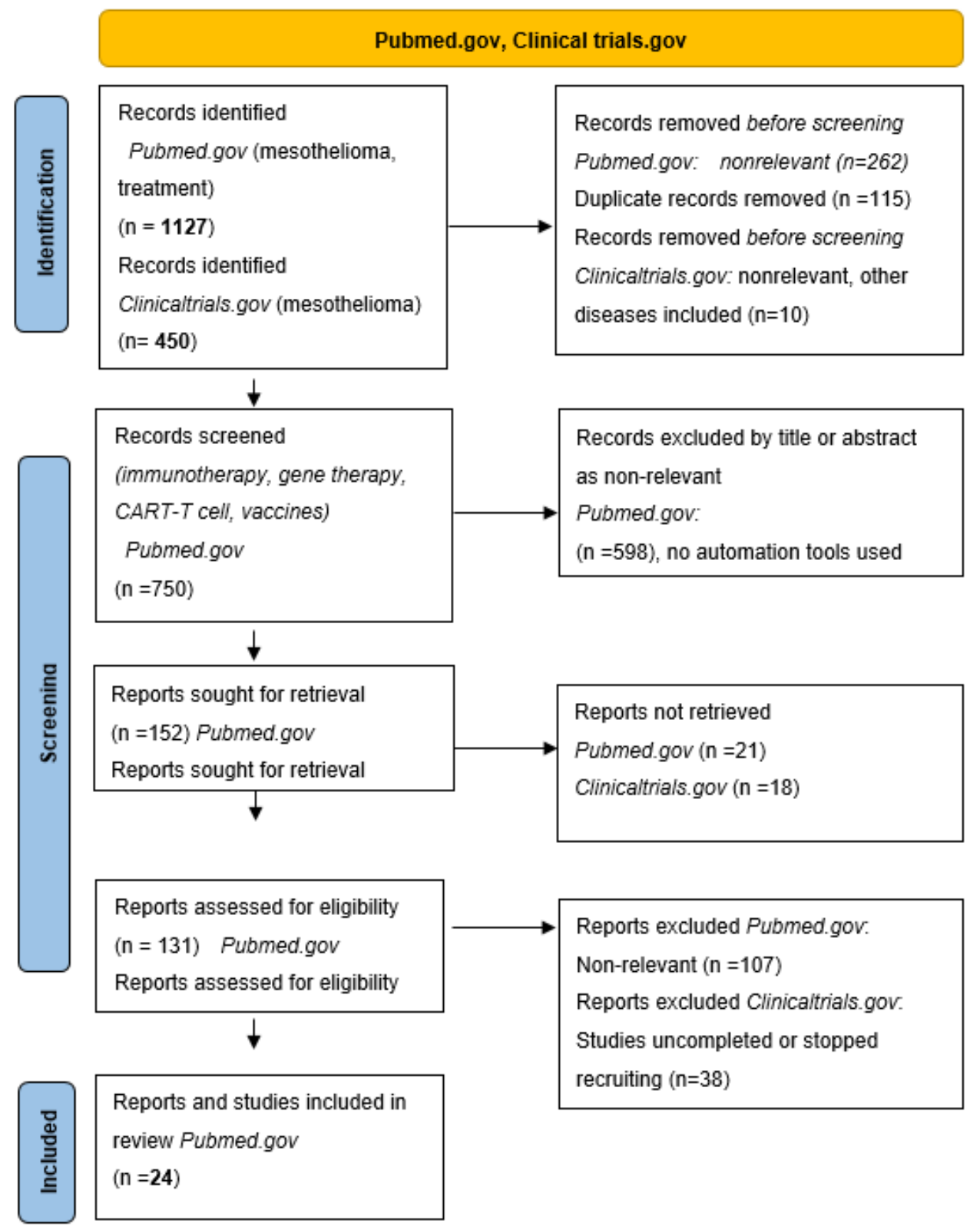

Figure 1. PRISMA flow diagram. 


\section{Results and Discussion}

\subsection{Immunotherapy in Mesothelioma, Checkpoint Inhibitors and New Combinations with Chemotherapy Treatment}

Immunotherapy has become another pillar of cancer treatment next to the classic chemotherapy, radiotherapy, and surgery approaches in the recent decade. Immunotherapy has been the revolutionary new therapy in lung cancer and melanoma, where treatment options were also limited. Immunotherapeutic agents are applied as first-line treatments $[29,30]$. However, immunotherapy is still used as a second-line treatment in mesothelioma according to the NCCN guidelines [18]. Combinations of PD1 receptor inhibitors nivolumab and pembrolizumab or monoclonal antibody ipilimumab that inhibits cytotoxic T lymphocyte protein 4 (CTLA-4) can be used in mesothelioma. The most significant benefit seemed to be from the combination of nivolumab/ipilimumab with median overall survival of 15.9 months. However, the toxicity of this combination therapy was higher (grade 3 or 4) than in the single-agent arm [31]. The CheckMate 743 trial used the combination of nivolumab/ipilimumab in the first-line setting. This study included 713 primarily unresectable mesothelioma patients and reported an overall survival advantage of 18.1 months over 14.1 months under a pemetrexed/carbo platinum regimen [32]. Another trial with pembrolizumab that included 26 patients with a performance status of WHO $0-1$ and failure of previous treatment reported up to 18 months long overall survival. The overall response rate in these immunotherapy trials was around 20-30\% [33]. However, when we consider potentially severe toxicities, such as pneumonitis, the results of these trials were far from miraculous [34]. Nevertheless, trials such as the CheckMate, MARS, and Keynote 028 have played an essential role in placing immunotherapy into clinical practice [31-33].

However, immunotherapy is not a "magical bullet" treatment in mesothelioma, and combination treatments that challenge the mechanisms of immunological resistance need to be considered. In particular, the search for novel immunotherapy agents and their application has shifted towards overcoming immunological resistance mechanisms present in mesothelioma. The answer to immunotherapy resistance in mesothelioma could be found in its complex microenvironment. Cancer-associated fibroblasts, T-cells, tumor-associated macrophages (TAMs), and myeloid-derived suppressor cells (MDSC) have immunosuppressive roles in mesothelioma. TAMs, as an example, develop an immunosuppressive phenotype in mesothelioma [35]. Furthermore, mesothelioma secretomes include granulocyte colony-stimulating factors (G-CSF) that stimulate the proliferation of MDSC, which inhibits the proliferation of T-cells [36].

Another more precise mechanism of immunotherapy resistance has been elucidated recently. V-domain Ig-containing suppressor of T-cell activation (VISTA) is an immune checkpoint gene that inhibits anti-tumor immune responses. The Cancer Genome Atlas Study suggested that pleural mesothelioma displays the highest expression levels of VISTA among all the cancers studied. In contrast, non-small lung cancer does not express VISTA. Therefore, VISTA has become one of the possible targets for overcoming immunotherapy resistance and a molecular target to improve the immune downregulation in mesothelioma $[37,38]$.

Investigating specific and complex mesothelioma microenvironment in overcoming immunotherapy resistance gives new purpose to old chemotherapeutic agents. Cisplatin might be a promising treatment for combining immune checkpoint blocking antibodies since the studied cell lines were most susceptible to the combination treatment. It was proposed that most chemotherapy agents can enrich the microenvironment in CD3 or CD8 lymphocytes [39]. A combination of gemcitabine and anti-PD1 resulted in partial clinical response in two patients resistant to either single agent [40].

Table 2 presents an overview and more details of studies on immunotherapy in mesothelioma. However, specific immunohistological features of mesothelioma may suggest that a simple application of immune checkpoint inhibitors may not be efficient. The arising challenges in mesothelioma immunotherapy are in overcoming the immunological resistance. 
Table 2. Immunotherapy in mesothelioma.

\begin{tabular}{|c|c|c|c|c|c|c|}
\hline $\begin{array}{c}\text { Therapeutic Agent } \\
\text { Used }\end{array}$ & $\begin{array}{l}\text { Mono or Combination } \\
\text { Therapy }\end{array}$ & $\begin{array}{l}\text { Endpoints of the } \\
\text { Study }\end{array}$ & $\begin{array}{l}\text { No of the Patients } \\
\text { Included }\end{array}$ & $\begin{array}{l}\text { Significant Findings, } \\
\text { Safety, Disease } \\
\text { Response, Disease } \\
\text { Control }\end{array}$ & $\begin{array}{c}\text { Type of Study } \\
\text { (Preclinical/Clinical) }\end{array}$ & Reference \\
\hline $\begin{array}{l}\text { Anti PD1 nivolumab } \\
\text { and anti CTLA4 } \\
\text { ipilimumab, as } \\
\text { monotherapy with } \\
\text { nivolumab or } \\
\text { in combination }\end{array}$ & $\begin{array}{l}\text { Nivolumab/ipilimumab } \\
\text { combination }\end{array}$ & $\begin{array}{l}\text { Phase II trial to assess } \\
\text { the short-term efficacy } \\
\text { and toxicity in a } \\
\text { smaller group } \\
\text { of patients }\end{array}$ & 108 patients & $\begin{array}{l}\text { Slightly more toxicity } \\
\text { in the combination arm, } \\
12 \text {-week disease control } \\
\text { in } 40 \% \text { of patients in } \\
\text { the combination arm }\end{array}$ & clinical & Scherpereel A et al. [31] \\
\hline $\begin{array}{l}\text { Pembrolizumab, } \\
\text { PDL1 antibody }\end{array}$ & Monotherapy/pembro & $\begin{array}{l}\text { Phase } \mathrm{Ib} \text { trial to assess } \\
\text { the safety and response } \\
\text { in a smaller group of } \\
\text { patients ( } 25 \text { patients) }\end{array}$ & 25 & $\begin{array}{l}\text { Well tolerated with } \\
\text { minimal grade III or } \\
\text { above toxicity }(4 \%), \\
\text { partial response in } 25 \% \text {, } \\
\text { and stable disease in } \\
52 \% \text { of patients }\end{array}$ & clinical & Alley EW et al. [32] \\
\hline Review article & Review & $\begin{array}{l}\text { To review major } \\
\text { mechanisms involved } \\
\text { in immune resistance } \\
\text { of mesothelioma }\end{array}$ & Review & $\begin{array}{l}\text { TAM cells, dendritic } \\
\text { cells, fibroblasts, and } \\
\text { T-cells have a major } \\
\text { role in immune } \\
\text { resistance }\end{array}$ & review & Chu GJ et al. [35] \\
\hline $\begin{array}{c}\text { V-domain } \\
\text { Ig-containing } \\
\text { suppressor of T-cell } \\
\text { activation (VISTA) as } \\
\text { immune } \\
\text { response inhibitor }\end{array}$ & Potential monotherapy & $\begin{array}{l}\text { To study the role of } \\
\text { VISTA in large } \\
\text { mesothelioma samples } \\
\text { of different } \\
\text { mesothelioma } \\
\text { histological types }\end{array}$ & $\begin{array}{l}319 \text { mesothelioma } \\
\text { tissue samples }\end{array}$ & $\begin{array}{l}\text { VISTA is an important } \\
\text { immune response } \\
\text { inhibitor in } \\
\text { mesothelioma, can be a } \\
\text { drug target, prognostic } \\
\text { cut off at } 40 \%\end{array}$ & $\begin{array}{l}\text { preclinical, } \\
\text { mesothelioma } \\
\text { tissue lines }\end{array}$ & Muller S et al. [37] \\
\hline $\begin{array}{l}\text { Review of different } \\
\text { treatment modalities }\end{array}$ & $\begin{array}{l}\text { Chemotherapy, } \\
\text { chemoradiotherapy }\end{array}$ & $\begin{array}{l}\text { To review the role of } \\
\text { standard treatments in } \\
\text { immunomodulation } \\
\text { of mesothelioma }\end{array}$ & 8850 from 110 studies & $\begin{array}{l}\text { Different, standard } \\
\text { chemotherapy } \\
\text { regimens can increase } \\
\text { CD3 and CD8 } \\
\text { lymphocytes, making } \\
\text { mesothelioma more } \\
\text { susceptible } \\
\text { to immunotherapy }\end{array}$ & review & Van den Ende et al. [39] \\
\hline $\begin{array}{l}\text { Gemcitabine and } \\
\text { anti PD1 }\end{array}$ & $\begin{array}{l}\text { Gemcitabine and anti } \\
\text { PD1 combination }\end{array}$ & $\begin{array}{l}\text { To assess gemcitabine } \\
\text { as a potential } \\
\text { immunomodulator }\end{array}$ & $\begin{array}{l}\text { Preclinical model, } \\
2 \text { patients }\end{array}$ & $\begin{array}{l}\text { Better tumor control } \\
\text { and survival, nullified } \\
\text { if dexamethasone } \\
\text { added, clinical } \\
\text { response in } 2 \text { patients }\end{array}$ & $\begin{array}{l}\text { preclinical model and } \\
\text { two treated patients }\end{array}$ & Tallon de L et al. [40] \\
\hline
\end{tabular}

Dendritic cell therapy has been used to turn the immunologically "cold" tumor environment into an "inflamed" state in three studies that reported $20.7 \%$ overall survival at five years [41-44]. This idea of dendritic cell therapy evolved further in the DENIM trial. The patients were randomized into the dendritic cell therapy and best supportive care arm in this trial. The primary endpoint of this trial which is still recruiting, is overall survival, with secondary endpoints being progression-free survival, safety, efficacy, and quality of life. The results of this trial are still pending [45].

\subsection{Therapeutic Cancer Vaccines in Mesothelioma}

The modest response to immunotherapy and mesothelioma microenvironment changes warrants new approaches involving different treatment options. Oncolytic vaccines with viral vectors have been investigated in mesothelioma as a standalone treatment or in combinations involving chemo and immunotherapy. Infection with the Edmonston vaccine strain (MV-Edm) derivative of measles virus resulted in lysis of cancer cells and was tested in clinical trials for numerous tumor types, including mesothelioma. The MV-Edm receptor Cluster of Differentiation 46 (CD46) level was significantly higher in mesothelioma cells than in control cells. MV-Edm treatment of mesothelioma cell lines reduced cell viability and invoked apoptotic cell death [46]. Newer studies, however, rely on modifying the immune response. Tan et al. used an adenoviral vector to create an rAAV-soluble PD1 (sPD1)-TWIST1 vaccine that ultimately induced Twist related protein 1 (TWIST1) Tlymphocyte cell response, thereby recruiting T-cells in the murine mesothelioma model [47]. These approaches of breaking immune tolerance led to clinical trials of oncolytic vaccines. In total, 28 concluded and ongoing trials of mesothelioma vaccines are registered in ClincalTrials.gov. Table 3 summarizes the published studies on therapeutic cancer vaccines in mesothelioma. 
Table 3. Overview of published studies on therapeutic cancer vaccines in mesothelioma.

\begin{tabular}{|c|c|c|c|c|c|c|}
\hline $\begin{array}{c}\text { Used Therapeutic } \\
\text { Agent }\end{array}$ & $\begin{array}{l}\text { Mono or Combined } \\
\text { Therapy }\end{array}$ & $\begin{array}{l}\text { Endpoints of the } \\
\text { Study }\end{array}$ & $\begin{array}{l}\text { No of the Patients } \\
\text { Included }\end{array}$ & $\begin{array}{c}\text { Major Findings, } \\
\text { Overall Survival (OS), } \\
\text { Disease Control, } \\
\text { Progression-Free } \\
\text { Survival }\end{array}$ & $\begin{array}{c}\text { Type of Study } \\
\text { (Preclinical/Clinical) }\end{array}$ & Reference \\
\hline $\begin{array}{l}\text { Nivolumab/Ipilimumab } \\
\text { in one arm, telomerase } \\
\text { UV1 vaccine in the } \\
\text { experimental arm, } \\
\text { second-line treatment }\end{array}$ & $\begin{array}{l}\text { Combination of } \\
\text { immunotherapy and } \\
\text { vaccine therapy }\end{array}$ & $\begin{array}{l}\text { To improve the efficacy } \\
\text { of checkpoint inhibitors } \\
\text { while overcoming } \\
\text { resistance to } \\
\text { immune therapy }\end{array}$ & 118 & results pending & clinical phase II study & $\begin{array}{l}\text { Haakensen VD } \\
\text { et al. [48] }\end{array}$ \\
\hline $\begin{array}{c}\text { Pemetrexed/Cisplatin, } \\
\text { TroVax }{ }^{\circledR} \text { (pox virus } \\
\text { viral vector) }\end{array}$ & $\begin{array}{l}\text { Chemotherapy and pox } \\
\text { virus combination }\end{array}$ & $\begin{array}{l}\text { The induction of } \\
\text { cellular or humoral } \\
\text { anti-5T4 } \\
\text { immune response }\end{array}$ & 27 & $\begin{array}{l}\text { disease control in } 87 \% \\
\text { of patients, overall } \\
\text { survival } 10.9 \text { months, } \\
\text { progression-free } \\
\text { survival } 6.8 \text { months }\end{array}$ & clinical phase II study & Lester JF et al. [49] \\
\hline $\begin{array}{l}\text { GMCSF expressing } \\
\text { oncolytic adenovirus } \\
\text { ONCOS } 102 \text { and } \\
\text { Pemetrexed/Cisplatin }\end{array}$ & $\begin{array}{l}\text { Chemotherapy and } \\
\text { adenovirus } \\
\text { combination }\end{array}$ & $\begin{array}{l}\text { To determine safety, } \\
\text { response rate, overall } \\
\text { survival, the } \\
\text { correlation between } \\
\text { immune activation and } \\
\text { clinical outcome }\end{array}$ & 30 & $\begin{array}{l}\text { completed May 2020, } \\
\text { results pending }\end{array}$ & clinical study & Aix SP et al. [50] \\
\hline
\end{tabular}

An ongoing NIPU trial is a randomized phase II trial that included 118 patients that received prior chemotherapy and were inoperable. In one arm, patients received nivolumab and ipilimumab treatment until progression, and in the second experimental arm, the telomerase UV1 vaccine was applied in the first three months of treatment. The results are still pending [48].

The SKOPOS trial selected a combination of pemetrexed/cisplatin-based treatment with Trovax vaccine, based on a pox viral vector 5T4 tumor-associated antigen. The trial included 27 patients with locally advanced or metastatic disease who received the vaccine two weeks before chemotherapy with the combined regimen and again 24 weeks postchemotherapy. The phase I/II study concluded with a stable disease control of $87 \%$ and adverse effects compared to chemotherapy alone [49].

Another vaccine, which is perhaps the most promising regarding mesothelioma, is a granulocyte-macrophage colony-stimulating factor (GMCSF)-expressing oncolytic adenovirus, ONCOS-102. A phase II trial with 24 included patients was concluded in May 2020 and compared oncolytic vaccine treatment ONCOS-102 and standard treatment with pemetrexed/cisplatin. The results of this trial are still pending [50].

\subsection{CAR-T Cell Therapy in Mesothelioma}

Due to the limited efficacy of checkpoint inhibitors in mesothelioma, new approaches to immunotherapy are investigated, among them chimeric antigen receptor T-cell (CAR-T) therapy. CAR-T cells are genetically engineered to recognize cancer cell-surface antigen and lyse cancer cells [51]. The target for CAR-T cells in mesothelioma and other solid cancers is mesothelin, which is abundantly expressed in mesothelioma [52,53]. Other emerging potential CAR-T targets include podoplanin (PDPN), a transmembrane receptor glycoprotein upregulated on transformed cells, cancer-associated fibroblasts, and inflammatory macrophages that contribute to cancer progression. In particular, PDPN increases tumor cell clonal capacity, epithelial-mesenchymal transition, migration, invasion, metastasis, and inflammation [54].

However, clinical trials are limited to mesothelin-related CAR-T cells (CAR-T cell meso). After searching the ClinicalTrials.gov website for CAR-T cell and mesothelioma, 11 trials were found. Of these trials, three were completed, one terminated, and others still ongoing. It is to be noticed that all of these trials are still in phase I [28]. The first trial included 25 mesothelioma patients with advanced disease, and CAR- T cells were injected intrapleural. The other two included patients who had pleural involvement of breast cancer. Most of the patients received pembrolizumab since the animal model studies showed that PD1 inhibition enhances CAR-T cell activity. The median overall survival in these patients was 23.9 months [55].

Another CAR-T cell meso included patients with solid cancers, including ovarian and mesothelioma. The 15 included patients were pretreated with cyclophosphamide and were 
chemo-refractory. CAR-T cells were applied through lentiviral transduction. This trial did not present any clinical benefit beyond stable disease, and the CAR-T cells were detectable in blood only for 28 days [56].

Table 4 summarizes the published studies on CAR-T cell therapy in mesothelioma. We may conclude from the clinical trials performed so far that CAR-T cell therapy is safe in mesothelioma. However, its efficacy needs to be further evaluated. There seem to be difficulties with the appropriate application of CAR-T cell therapy in solid tumors that need to be solved. From the trials mentioned above, we can understand that intrapleural application may be somewhat better than intravenous. The choice of viral vectors still needs to be studied further. However, the most considerable challenge in CAR-T cell therapy in mesothelioma seems to be the microenvironment that makes mesothelioma an immunologically "cold" tumor [57]. Therefore, efforts have been made in modulating this microenvironment with other agents, such as checkpoint inhibitors or classic chemotherapeutics.

Table 4. Overview of Chimeric Antigen Receptor (CAR)-T cell therapy in mesothelioma.

\begin{tabular}{|c|c|c|c|c|c|c|}
\hline $\begin{array}{c}\text { Used Therapeutic } \\
\text { Agent }\end{array}$ & $\begin{array}{c}\text { Mono or Combined } \\
\text { Therapy }\end{array}$ & $\begin{array}{l}\text { Endpoints of the } \\
\text { Study }\end{array}$ & $\begin{array}{l}\text { No of the Patients } \\
\text { Included }\end{array}$ & $\begin{array}{c}\text { Major Findings, } \\
\text { Tolerance, Disease } \\
\text { Progression, Disease } \\
\text { Control }\end{array}$ & $\begin{array}{c}\text { Type of Study } \\
\text { (Preclinical/Clinical) }\end{array}$ & Reference \\
\hline $\begin{array}{l}\text { Anti mesothelin } \\
\text { chimeric antigen } \\
\text { receptor Tcell } \\
\text { (anti-MSLN } \\
\text { CAR-T cells) }\end{array}$ & Review & $\begin{array}{l}\text { Review of phase I } \\
\text { studies to assess the } \\
\text { safety and efficacy of } \\
\text { new treatment }\end{array}$ & - & $\begin{array}{l}\text { Anti MSLN CAR T is } \\
\text { safe, and efficacy is low } \\
\text { due to mesothelioma } \\
\text { microenvironment } \\
\text { specifics }\end{array}$ & Clinical phase I, review & Castelletti L et al. [52] \\
\hline $\begin{array}{l}\text { Podoplanin, anti PDPN } \\
\text { CAR-T cells }\end{array}$ & Preclinical & $\begin{array}{l}\text { To study if this CAR-T } \\
\text { cell can inhibit local } \\
\text { tumor invasion } \\
\text { and progression }\end{array}$ & preclinical & $\begin{array}{l}\text { This CAR-T can be } \\
\text { used as a biomarker or } \\
\text { treatment target }\end{array}$ & Preclinical, cell lines & Krishnan $\mathrm{H}$ et al. [54] \\
\hline $\begin{array}{l}\text { MSLN CAR-T cells, } \\
\text { anti PD1 } \\
\text { pembrolizumab }\end{array}$ & $\begin{array}{c}\text { Immuno/CAR-T } \\
\text { combination }\end{array}$ & $\begin{array}{l}\text { To study if this } \\
\text { combined } \\
\text { immunotherapy } \\
\text { approach is safe and } \\
\text { effective in } \\
\text { mesothelioma patients }\end{array}$ & 25 & $\begin{array}{l}\text { Stable disease after } 6 \\
\text { months in } 8 \text { patients, } \\
\text { complete radiological } \\
\text { response in } 2\end{array}$ & Clinical phase I & $\begin{array}{l}\text { Adusumilli PS } \\
\text { et al. [55] }\end{array}$ \\
\hline $\begin{array}{l}\text { MSLN CAR-T cells, } \\
\text { cyclophosphamide (a } \\
\text { chemotherapeutic agent) }\end{array}$ & $\begin{array}{l}\text { Chemotherapy/ } \\
\text { CAR-T cells }\end{array}$ & $\begin{array}{l}\text { To study the safety and } \\
\text { efficacy of this CAR-T } \\
\text { cells chemotherapy } \\
\text { combination }\end{array}$ & 15 & $\begin{array}{l}\text { Well tolerated, } \\
\text { cyclophosphamide } \\
\text { enhances CAR-T cell } \\
\text { expansion, low efficacy }\end{array}$ & $\begin{array}{l}\text { Clinical phase I, } 15 \\
\text { patients with } \\
\text { mesothelioma, ovarian } \\
\text { cancer, and pancreatic } \\
\text { adenocarcinoma }\end{array}$ & Hass AR et al. [56] \\
\hline
\end{tabular}

\subsection{Gene and Genetic Therapy Principles in Mesothelioma}

Therapy, based on chromosomal rearrangements, micro RNA (miRNA), short hairpin RNA (shRNA), and transcriptome technology, has been investigated on mesothelioma cell lines and animal models (Table 5).

Chromosomal rearrangements result in novel, unique gene junctions that can be expressed and potentially result in the presentation of several neoantigens. These predicted neoantigens can be presented by tumors on major histocompatibility complex (MHC) proteins and are correlated with clonal expansion of tumor-infiltrating $\mathrm{T}$ cells. T cells responsive to these neoantigens have been identified in a patient's circulation. The analysis of chromosomal rearrangements in mesothelioma can improve immunotherapeutic strategies and the selection of patients to receive immunotherapy and be applied in anti-tumor vaccines [58]. Furthermore, therapeutic principles have been studied in spliceosome's genes-the high expression of splicing factor 3b, subunit 1 (SF3B1) correlated with poor clinical outcomes. SF3b modulators (Pladienolide-B, E7107, Meayamycin-B) showed potent cytotoxic activity in vitro [59].

Post-transcriptional strategies, such as RNA interference (RNAi), can have potent gene silencing in several cancers. Therefore, novel therapeutic formulations, such as DFP1082, were developed. DFP-10825 was composed of chemically synthesized short hairpin RNA (shRNA) against thymidylate synthase (TS), a key enzyme for cancer proliferation. This therapeutic approach was studied in animal models and is now waiting for clinical trials [60,61].

Another post-transcriptional treatment strategy involved different micro RNAs that have been studied extensively in mesothelioma. MiRNAs can be up- or downregulated 
in mesothelioma tissue. An example is the miR 15/16 family that is downregulated with fibroblast growth factor (FGF). The transfection with miR 15/16 resulted in binding to the FGF receptor and diminished growth of mesothelioma cell lines [62].

MiR-126 was suppressed in asbestos-related malignancies. Furthermore, the application of miR-126 to the endothelial cells of mesothelioma reduced cell growth by reducing angiogenesis [63]. On the other hand, overexpression of miR-137 was linked to poor patient survival. However, the combination of miR-137 and Y-box binding protein 1 (YBX1) resulted in a tumor-suppressive function [64].

Table 5. Overview of preclinical studies of genetic therapy in mesothelioma.

\begin{tabular}{|c|c|c|c|c|}
\hline Used Therapeutic Agent & Endpoints of the Study & Major Findings & Type of Study & Reference \\
\hline $\begin{array}{l}\text { Pladienolide-B, E7107, } \\
\text { Meayamycin-B }\end{array}$ & $\begin{array}{l}\text { To study if splicing modulators can alter } \\
\text { cell cycle and apoptosis }\end{array}$ & $\begin{array}{l}\text { Splicing modulators impair } \\
\text { mesothelioma cancer cell viability }\end{array}$ & Preclinical, mesothelioma cell lines & Sciarrillo $R$ et al. [59] \\
\hline DFP-10825 (shRNA) & $\begin{array}{l}\text { To study if cationic liposomes with } \\
\text { shRNA targeting thymidylate synthase } \\
\text { inhibit cell growth in } \\
\text { peritoneal mesothelioma }\end{array}$ & $\begin{array}{l}\text { High therapeutic effect without } \\
\text { severe side effects }\end{array}$ & Preclinical, mouse model & Ando $\mathrm{H}$ et al. [60] \\
\hline $\mathrm{miR}-15 / 16$ & $\begin{array}{l}\text { To study downregulation of fibroblast } \\
\text { growth factor (FGF) by miR-15/16 }\end{array}$ & $\begin{array}{l}\text { miR-15/16 can downregulate FGF } \\
\text { and inhibit the growth of } \\
\text { mesothelioma cells }\end{array}$ & Preclinical, mesothelioma cell lines & Schelch K et al. [62] \\
\hline miR-137 & $\begin{array}{l}\text { To study if Y box binding protein } 1 \text { gene } \\
\text { (YBX1) can downregulate miR-137 } \\
\text { levels in mesothelioma }\end{array}$ & $\begin{array}{l}\text { miR-137 combination with YBX1 can } \\
\text { suppress growth, invasion, and } \\
\text { migration of mesothelioma cells }\end{array}$ & Preclinical, mesothelioma cell lines & Johnson TG et al. [64] \\
\hline miR-182/miR-183 & $\begin{array}{c}\text { To study if inhibition of } \\
\text { miR-182/miR- } 183 \text { can reduce } \\
\text { proliferation and migration of } \\
\text { mesothelioma cells }\end{array}$ & $\begin{array}{l}\text { miR- } 182 / \mathrm{miR}-183 \text { inhibitors can } \\
\text { reduce the proliferation and } \\
\text { migration of mesothelioma cells }\end{array}$ & Preclinical, mesothelioma cell lines & Suzuki R et al. [65] \\
\hline miR-126 & $\begin{array}{l}\text { To study if the re-expression of miR-126 } \\
\text { can inhibit cell invasion } \\
\text { and proliferation }\end{array}$ & $\begin{array}{l}\text { MiR- } 126 \text { induces G1/S cell cycle } \\
\text { arrest and inhibits proliferation }\end{array}$ & Preclinical, mesothelioma cell lines & Singh A et al. [66] \\
\hline
\end{tabular}

Other potential targets of dysregulation of miRNA in mesothelioma are miR-182/miR183 family and miR-206. Inhibition of miR-182 and miR-183 reduced cell proliferation ability via upregulation of forkhead box 1(FOXO1) and its downstream targets, namely, p27 [65]. When miR-206 was ectopically re-expressed in mesothelioma cells and delivered to tumor xenografts in mice, it exerted significant cell killing by suppressing multiple components of the receptor-tyrosine-kinase-Ras-cell-cycle-signaling network. This miR-206-targeting mechanism manifested as induced G1/S cell cycle arrest [66].

The retrieved data indicate that the currently investigated and potential novel genetic approaches offer new possibilities of precision therapy in mesothelioma [66].

\section{Methods}

We searched the available literature in the PubMed.gov [27] and ClinicalTrials.gov [28] databases. The PubMed.gov search was limited to the data published from the year 2000 up to the year 2021. We used the combination of keywords "immunotherapy and mesothelioma", "CAR-T cell therapy and mesothelioma", "gene and genetic therapy and mesothelioma". The ClinicalTrials.gov database search was limited to the completed studies with the keywords "mesothelioma" and "therapy". The PRISMA flow diagram of the search is shown in Figure 1. We retrieved 24 papers from Pubmed.gov exploring the role of novel treatments in mesothelioma after manually screening 1127 records. We stratified these studies into three groups: (1) immunotherapy in mesothelioma; (2) cancer vaccines in mesothelioma; (3) CAR-T cell therapy in mesothelioma; (4) gene and genetic therapy in mesothelioma. We further searched for published and ongoing clinical trials in novel mesothelioma treatments on ClinicalTrials.gov, manually screening 450 trials and retrieving 12 trials significant to this review.

To minimize the publication bias of our systematic literature search, we have reported not only the positive sides, but also the limitations of specific therapeutic approaches. Furthermore, we also included information on clinical trials. Although in the manuscript's text and tables we have focused on clinical trials that have published their data, extensive 
information on all clinical trials is available in the Supplementary Tables (Supplementary Tables S1-S3), thus minimizing any bias with regard to clinical trials.

\section{Conclusions}

Therapeutic approaches in mesothelioma thus far have been uniform and limited to first-line, and possibly second-line, treatment. New advances in immunotherapy offer a different view on this immunologically "cold" disease. While the results of checkpoint inhibitory therapy have been modest, the research in the mesothelioma tumor microenvironment is ongoing. The combination of understanding the mesothelioma microenvironment and the genetic drivers that modulate it seems to be the future of precision-based therapy in mesothelioma.

Supplementary Materials: The following supporting information can be downloaded at: https: //www.mdpi.com/article/10.3390/ijms23041975/s1.

Author Contributions: The authors declare that they have equal contribution in the research and writing of this manuscript. All authors have read and agreed to the published version of the manuscript.

Funding: This study was funded by the Javna Agencija za Raziskovalno Dejavnost RS (Slovenian Research Agency, ARRS), research grants P1-170, L3-8203, and L3-2622.

Institutional Review Board Statement: Not applicable.

Informed Consent Statement: Not applicable.

Data Availability Statement: All the data are presented within the article. Any additional information is available on request from the corresponding author.

Conflicts of Interest: The authors declare that the research was conducted without any commercial or financial relationships that could be construed as a potential conflict of interest.

\section{References}

1. Brims, F. Epidemiology and Clinical Aspects of Malignant Pleural Mesothelioma. Cancers 2021, 13, 4194. [CrossRef] [PubMed]

2. WHO. Global Mesothelioma Deaths Reported to the World Health Organization between 1994 and 2008. Available online: https://www.who.int/bulletin/volumes/89/10/11-086678/en/ (accessed on 20 September 2020).

3. Frost, G. The latency period of mesothelioma among a cohort of British asbestos workers (1978-2005). Br. J. Cancer 2013, 109, 1965-1973. [CrossRef] [PubMed]

4. Boffetta, P.; Donato, F.; Pira, E.; Luu, H.N.; La Vecchia, C. Risk of mesothelioma after cessation of asbestos exposure: A systematic review and meta-regression. Int. Arch. Occup. Environ. Health 2019, 92, 949-957. [CrossRef] [PubMed]

5. Hiltbrunner, S.; Mannarino, L.; Kirschner, M.B.; Opitz, I.; Rigutto, A.; Laure, A.; Lia, M.; Nozza, P.; Maconi, A.; Marchini, S.; et al. Tumor Immune Microenvironment and Genetic Alterations in Mesothelioma. Front. Oncol. 2021, 11, 660039. [CrossRef] [PubMed]

6. Sekido, Y. Molecular pathogenesis of malignant mesothelioma. Carcinogenesis 2013, 34, 1413-1419. [CrossRef] [PubMed]

7. Kobayashi, N.; Toyooka, S.; Yanai, H.; Soh, J.; Fujimoto, N.; Yamamoto, H.; Ichihara, S.; Kimura, K.; Ichimura, K.; Sano, Y.; et al. Frequent p16 inactivation by homozygous deletion or methylation is associated with a poor prognosis in Japanese patients with pleural mesothelioma. Lung Cancer 2008, 62, 120-125. [CrossRef] [PubMed]

8. Hamasaki, M.; Matsumoto, S.; Abe, S.; Hamatake, D.; Kamei, T.; Hiroshima, K.; Kawahara, K.; Sato, A.; Tsujimura, T.; Nakatani, Y.; et al. Low homozygous/high heterozygous deletion status by p16 FISH correlates with a better prognostic group than high homozygous deletion status in malignant pleural mesothelioma. Lung Cancer 2016, 99, 155-161. [CrossRef] [PubMed]

9. Hwang, H.; Tse, C.; Rodriguez, S.; Gown, A.; Churg, A. p16 FISH Deletion in Surface Epithelial Mesothelial Proliferations Is Predictive of Underlying Invasive Mesothelioma. Am. J. Surg. Pathol. 2014, 38, 681-688. [CrossRef]

10. Asciak, R.; George, V.; Rahman, N.M. Update on biology and management of mesothelioma. Eur. Respir. Rev. 2021, $30,200226$. [CrossRef] [PubMed]

11. Berzenji, L.; Van Schil, P.E.; Carp, L. The eighth TNM classification for malignant pleural mesothelioma. Transl. Lung Cancer Res. 2018, 7, 543-549. [CrossRef]

12. Beasley, M.B.; Galateau-Salle, F.; Dacic, S. Pleural mesothelioma classification update. Virchows Arch. 2021, 478, 59-72. [CrossRef] [PubMed]

13. Sugarbaker, D.J.; Heher, E.C.; Lee, T.H.; Couper, G.; Mentzer, S.; Corson, J.M.; Collins, J.J.; Shemin, R.; Pugatch, R.; Weissman, L. Extrapleural pneumonectomy, chemotherapy, and radiotherapy in the treatment of diffuse malignant pleural mesothelioma. $J$. Thorac. Cardiovasc. Surg. 1991, 102, 10-15. [CrossRef] 
14. Borrelli, E.P.; McGladrigan, C.G. A Review of Pharmacologic Management in the Treatment of Mesothelioma. Curr. Treat. Options Oncol. 2021, 22, 14. [CrossRef]

15. Wald, O.; Sugarbaker, D.J. New Concepts in the Treatment of Malignant Pleural Mesothelioma. Annu. Rev. Med. 2018, 69, 365-377. [CrossRef] [PubMed]

16. Kovac, V.; Zwitter, M.; Rajer, M.; Marin, A.; Debeljak, A.; Smrdel, U.; Vrankar, M. A phase II trial of low-dose gemcitabine in a prolonged infusion and cisplatin for malignant pleural mesothelioma. Anti-Cancer Drugs 2012, 23, 230-238. [CrossRef] [PubMed]

17. Baas, P.; Fennell, D.; Kerr, K.M.; Van Schil, P.E.; Haas, R.L.; Peters, S. Malignant pleural mesothelioma: ESMO Clinical Practice Guidelines for diagnosis, treatment and follow-up. Ann. Oncol. 2015, 26, v31-v39. [CrossRef]

18. National Comprehensive Cancer Network. Malignant Pleural Mesothelioma. Version 2. 2021. Available online: https://www. nccn.org/professionals/physician_gls/pdf/mpm.pdf (accessed on 18 September 2021).

19. Van Schil, P.E.; Baas, P.; Gaafar, R.; Maat, A.P.; Van de Pol, M.; Hasan, B.; Klomp, H.M.; Abdelrahman, A.M.; Welch, J.; Van Meerbeeck, J.P. Trimodality therapy for malignant pleural mesothelioma: Results from an EORTC phase II multicentre trial. Eur. Respir. J. 2010, 36, 1362-1369. [CrossRef]

20. Cho, B.C.J.; Donahoe, L.; Bradbury, P.A.; Leighl, N.; Keshavjee, S.; Hope, A.; Pal, P.; Cabanero, M.; Czarnecka, K.; McRae, K.; et al. Surgery for malignant pleural mesothelioma after radiotherapy (SMART): Final results from a single-centre, phase 2 trial. Lancet Oncol. 2021, 22, 190-197. [CrossRef]

21. Zhao, Z.-Y.; Zhao, S.-S.; Ren, M.; Liu, Z.-L.; Li, Z.; Yang, L. Effect of hyperthermic intrathoracic chemotherapy on the malignant pleural mesothelioma: A systematic review and meta-analysis. Oncotarget 2017, 8, 100640-100647. [CrossRef]

22. Quispel-Janssen, J.; van der Noort, V.; de Vries, J.F.; Zimmerman, M.; Lalezari, F.; Thunnissen, E.; Monkhorst, K.; Schouten, R.; Schunselaar, L.; Disselhorst, M.; et al. Programmed Death 1 Blockade With Nivolumab in Patients With Recurrent Malignant Pleural Mesothelioma. J. Thorac. Oncol. 2018, 13, 1569-1576. [CrossRef]

23. Hyde-Barrett, L. First New Drug Treatment for Mesothelioma Approved by FDA in Over 16 Years. 2020. Available online: https:/ / www.mesotheliomahelp.org/first-new-drug-treatment-for-mesothelioma-approved-by-fda-in-over-16-years / (accessed on 31 August 2021).

24. Marcq, E.; Van Audenaerde, J.R.; De Waele, J.; Jacobs, J.; Van Loenhout, J.; Cavents, G.; Pauwels, P.; van Meerbeeck, J.P.; Smits, E.L. Building a Bridge between Chemotherapy and Immunotherapy in Malignant Pleural Mesothelioma: Investigating the Effect of Chemotherapy on Immune Checkpoint Ex-pression. Int. J. Mol. Sci. 2019, 20, 4182. [CrossRef] [PubMed]

25. Disselhorst, M.; Baas, P. Chemotherapy options versus "novel" therapies: How should we treat patients with malignant pleural mesothelioma. Transl. Lung Cancer Res. 2020, 9, S77-S85. [CrossRef] [PubMed]

26. National Library of Medicine. Available online: https://pubmed.ncbi.nlm.nih.gov (accessed on 1 December 2021).

27. NIH. Clinical Trials.gov. Available online: https:/ / clinicaltrials.gov / (accessed on 10 January 2022).

28. Hamid, O.; Robert, C.; Daud, A.; Hodi, F.S.; Hwu, W.J.; Kefford, R.; Wolchok, J.D.; Hersey, P.; Joseph, R.; Weber, J.S.; et al. Five-year survival outcomes for patients with advanced melanoma treated with pembrolizumab in KEYNOTE-001. Ann. Oncol. 2019, 30, 582-588. [CrossRef] [PubMed]

29. Reck, M.; Rodríguez-Abreu, D.; Robinson, A.G.; Hui, R.; Csőszi, T.; Fülöp, A.; Gottfried, M.; Peled, N.; Tafreshi, A.; Cuffe, S.; et al. Pembrolizumab versus Chemotherapy for PD-L1-Positive Non-Small-Cell Lung Cancer. N. Engl. J. Med. 2016, 375, 1823-1833. [CrossRef] [PubMed]

30. Scherpereel, A.; Mazieres, J.; Greillier, L.; Lantuejoul, S.; Dô, P.; Bylicki, O.; Monnet, I.; Corre, R.; Audigier-Valette, C.; Locatelli-Sanchez, M.; et al. Nivolumab or nivolumab plus ipilimumab in patients with relapsed malignant pleural mesothelioma (IFCT-1501 MAPS2): A multicentre, open-label, randomised, non-comparative, phase 2 trial. Lancet Oncol. 2019, 20, 239-253. [CrossRef]

31. Baas, P.; Scherpereel, A.; Nowak, A.K.; Fujimoto, N.; Peters, S.; Tsao, A.S.; Mansfield, A.S.; Popat, S.; Jahan, T.; Antonia, S.; et al. First-line nivolumab plus ipilimumab in unresectable malignant pleural mesothelioma (CheckMate 743): A multicentre, randomised, open-label, phase 3 trial. Lancet 2021, 397, 375-386. [CrossRef]

32. Alley, E.W.; Lopez, J.; Santoro, A.; Morosky, A.; Saraf, S.; Piperdi, B.; van Brummelen, E. Clinical safety and activity of pembrolizumab in patients with malignant pleural mesothelioma (KEYNOTE-028): Preliminary results from a non-randomised, open-label, phase $1 \mathrm{~b}$ trial. Lancet Oncol. 2017, 18, 623-630. [CrossRef]

33. Yap, T.A.; Nakagawa, K.; Fujimoto, N.; Kuribayashi, K.; Guren, T.K.; Calabrò, L.; Shapira-Frommer, R.; Gao, B.; Kao, S.; Matos, I.; et al. Efficacy and safety of pembrolizumab in patients with advanced mesothelioma in the open-label, single-arm, phase 2 KEYNOTE-158 study. Lancet Respir. Med. 2021, 9, 613-621. [CrossRef]

34. Chu, G.J.; van Zandwijk, N.; Rasko, J.E.J. The Immune Microenvironment in Mesothelioma: Mechanisms of Resistance to Immu-notherapy. Front. Oncol. 2019, 9, 1366. [CrossRef]

35. Khanna, S.; Graef, S.; Mussai, F.; Thomas, A.; Wali, N.; Yenidunya, B.G.; Yuan, C.; Morrow, B.; Zhang, J.; Korangy, F.; et al. TumorDerived GM-CSF Promotes Granulocyte Immunosuppression in Mesothelioma Patients. Clin. Cancer Res. 2018, 24, 2859-2872. [CrossRef]

36. Muller, S.; Lai, W.V.; Adusumilli, P.S.; Desmeules, P.; Frosina, D.; Jungbluth, A.; Ni, A.; Eguchi, T.; Travis, W.D.; Ladanyi, M.; et al. V-domain Ig-containing suppressor of T-cell activation (VISTA), a potentially targetable immune checkpoint molecule, is highly expressed in epithelioid malignant pleural mesothelioma. Mod. Pathol. 2020, 33, 303-311. [CrossRef] [PubMed] 
37. Chung, Y.S.; Kim, M.; Cha, Y.J.; Kim, K.A.; Shim, H.S. Expression of V-set immunoregulatory receptor in malignant mesothelioma. Mod. Pathol. 2020, 33, 263-270. [CrossRef] [PubMed]

38. Van den Ende, T.; van den Boorn, H.G.; Hoonhout, N.M.; van Etten-Jamaludin, F.S.; Meijer, S.L.; Derks, S.; de Gruijl, T.D.; Bijlsma, M.F.; van Oijen, M.G.; van Laarhoven, H.W. Priming the tumor immune microenvironment with chemo(radio)therapy: A systematic review across tumor types. Biochim. Biophys. Acta Rev. Cancer 2020, 1874, 188386. [CrossRef] [PubMed]

39. De Lara, P.T.; Cecconi, V.; Hiltbrunner, S.; Yagita, H.; Friess, M.; Bode, B.; Opitz, I.; Vrugt, B.; Weder, W.; Stolzmann, P.; et al. Gemcitabine Synergizes with Immune Checkpoint Inhibitors and Overcomes Resistance in a Preclinical Model and Mesothelioma Patients. Clin. Cancer Res. 2018, 24, 6345-6354. [CrossRef] [PubMed]

40. Cornelissen, R.; Hegmans, J.P.J.J.; Maat, A.P.W.M.; Kaijen-Lambers, M.E.H.; Bezemer, K.; Hendriks, R.W.; Hoogsteden, H.C.; Aerts, J.G.J.V. Extended Tumor Control after Dendritic Cell Vaccination with Low-Dose Cyclophosphamide as Adjuvant Treatment in Patients with Malignant Pleural Mesothelioma. Am. J. Respir. Crit. Care Med. 2016, 193, 1023-1031. [CrossRef] [PubMed]

41. Hegmans, J.P.; Veltman, J.D.; Lambers, M.E.; de Vries, I.J.; Figdor, C.G.; WHendriks, R.; Hoogsteden, H.C.; Lambrecht, B.N.; Aerts, J.G. Consolidative dendritic cell-based im-munotherapy elicits cytotoxicity against malignant mesothelioma. Am. J. Respir. Crit. Care Med. 2010, 181, 1383-1390. [CrossRef]

42. Aerts, J.; Cornelissen, R.; Van Der Leest, C.; Hegmans, J.; Bezemer, K.; Kaijen-Lambers, M.; Eskens, F.; Braakman, E.; Van Der Holt B.; Hendriks, R.; et al. OA13.06 Autologous Dendritic Cells Loaded with Allogeneic Tumor Cell Lysate (Pheralys ${ }^{\circledR}$ ) in Patients with Mesothelioma: Final Results of a Phase I Study. J. Thorac. Oncol. 2017, 12, S295. [CrossRef]

43. Dumoulin, D.; Cornelissen, R.; Bezemer, K.; Baart, S.; Aerts, J. Long-Term Follow-Up of Mesothelioma Patients Treated with Dendritic Cell Therapy in Three Phase I/II Trials. Vaccines 2021, 9, 525. [CrossRef]

44. Belderbos, R.A.; Baas, P.; Berardi, R.; Cornelissen, R.; Fennell, D.A.; van Meerbeeck, J.P.; Scherpereel, A.; Vroman, H.; Aerts, J.G.J.V.; on behalf of the DENIM team. A multicenter, randomized, phase II/III study of dendritic cells loaded with allogeneic tumor cell lysate (MesoPher) in subjects with mesothelioma as maintenance therapy after chemotherapy: DENdritic cell Immunotherapy for Mesothelioma (DENIM) trial. Transl. Lung Cancer Res. 2019, 8, 280-285. [CrossRef]

45. Jacobson, B.A.; Sadiq, A.A.; Tang, S.; Jay-Dixon, J.; Patel, M.R.; Drees, J.; Sorenson, B.S.; Russell, S.J.; Kratzke, R.A. Cap-dependent translational control of oncolytic measles virus infection in malignant mesothelioma. Oncotarget 2017, 8, 63096-63109. [CrossRef]

46. Tan, Z.; Chiu, M.S.; Yan, C.W.; Man, K.; Chen, Z. Eliminating mesothelioma by AAV-vectored, PD1-based vaccination in the tumor microenvironment. Mol. Ther. Oncolytics 2021, 20, 373-386. [CrossRef] [PubMed]

47. Haakensen, V.D.; Nowak, A.K.; Ellingsen, E.B.; Farooqi, S.J.; Bjaanæs, M.M.; Horndalsveen, H.; Mcculloch, T.; Grundberg, O.; Cedres, S.M. Helland Åslaug NIPU: A randomised, open-label, phase II study evaluating nivolumab and ipilimumab combined with UV1 vaccination as second line treatment in patients with malignant mesothelioma. J. Transl. Med. 2021, 19, 232. [CrossRef] [PubMed]

48. Lester, J.F.; Casbard, A.C.; Al-Taei, S.; Harrop, R.; Katona, L.; Attanoos, R.L.; Tabi, Z.; Griffiths, G.O. A single centre phase II trial to assess the immuno-logical activity of TroVax ${ }^{\circledR}$ plus pemetrexed/cisplatin in patients with malignant pleural mesothelioma-The SKOPOS trial. Oncoimmunology 2018, 7, e1457597. [CrossRef]

49. Aix, S.P.; Viteri, S.; Bosch-Borrera, J.; Kuryk, L.; Hakonen, T.; Vetrhus, S.; Jäderberg, M.; Paz-Ares, L. ONCOS-102 and pemetrexed/cisplatin in patients with unresectable malignant pleural mesothelioma. Ann. Oncol. 2017, 28, v572. [CrossRef]

50. Chintala, N.K.; Restle, D.; Quach, H.; Saini, J.; Bellis, R.; Offin, M.; Beattie, J.; Adusumilli, P.S. CAR T-cell therapy for pleural mesothelioma: Rationale, preclinical development, and clinical trials. Lung Cancer 2021, 157, 48-59. [CrossRef]

51. Castelletti, L.; Yeo, D.; van Zandwijk, N.; Rasko, J.E.J. Anti-Mesothelin CAR T cell therapy for malignant mesothelioma. Biomark. Res. 2021, 9, 11. [CrossRef] [PubMed]

52. Ye, L.; Lou, Y.; Lu, L.; Fan, X. Mesothelin-targeted second generation CAR-T cells inhibit growth of mesothelin-expressing tumors in vivo. Exp. Ther. Med. 2019, 17, 739-747. [CrossRef]

53. Krishnan, H.; Rayes, J.; Miyashita, T.; Ishii, G.; Retzbach, E.; Sheehan, S.A.; Takemoto, A.; Chang, Y.-W.; Yoneda, K.; Asai, J.; et al Podoplanin: An emerging cancer biomarker and therapeutic target. Cancer Sci. 2018, 109, 1292-1299. [CrossRef]

54. Adusumilli, P.S.; Zauderer, M.G.; Rivière, I.; Solomon, S.B.; Rusch, V.W.; O'Cearbhaill, R.E.; Zhu, A.; Cheema, W.; Chintala, N.K.; Halton, E.; et al. A phase I trial of regional meso-thelin-targeted CAR T-cell therapy in patients with malignant pleural disease, in combination with the anti-PD-1 agent pem-brolizumab. Cancer Discov. 2021, 11, 2748-2763. [CrossRef]

55. Haas, A.R.; Tanyi, J.L.; O’hara, M.H.; Gladney, W.L.; Lacey, S.F.; Torigian, D.A.; Soulen, M.C.; Tian, L.; McGarvey, M.; Nelson, A.M.; et al. Phase I Study of Lentiviral-Transduced Chimeric Antigen Receptor-Modified T Cells Recognizing Mesothelin in Advanced Solid Cancers. Mol. Ther. 2019, 27, 1919-1929. [CrossRef]

56. Murthy, P.; Ekeke, C.N.; Russell, K.L.; Butler, S.C.; Wang, Y.; Luketich, J.D.; Soloff, A.C.; Dhupar, R.; Lotze, M.T. Making cold malignant pleural effusions hot: Driving novel immunotherapies. OncoImmunology 2019, 8, e1554969. [CrossRef] [PubMed]

57. Mansfield, A.S.; Peikert, T.; Vasmatzis, G. Chromosomal rearrangements and their neoantigenic potential in mesothelioma. Transl. Lung Cancer Res. 2020, 9, S92-S99. [CrossRef]

58. Sciarrillo, R.; Wojtuszkiewicz, A.; El Hassouni, B.; Funel, N.; Gandellini, P.; Lagerweij, T.; Buonamici, S.; Blijlevens, M.; van der Laan, E.A.; Zaffaroni, N.; et al. Splicing modulation as novel thera-peutic strategy against diffuse malignant peritoneal mesothelioma. EBioMedicine 2019, 39, 215-225. [CrossRef] [PubMed]

59. Ando, H.; Ishida, T. An RNAi therapeutic, DFP-10825, for intraperitoneal and intrapleural malignant cancers. Adv. Drug Deliv. Rev. 2020, 154-155, 27-36. [CrossRef] [PubMed] 
60. Barbarino, M.; Cesari, D.; Bottaro, M.; Luzzi, L.; Namagerdi, A.; Bertolino, F.M.; Bellan, C.; Proietti, F.; Somma, P.; Micheli, M.; et al. PRMT5 silencing selectively affects MTAP-deleted mesothelioma: In vitro evidence of a novel promising approach. J. Cell. Mol. Med. 2020, 24, 5565-5577. [CrossRef] [PubMed]

61. Schelch, K.; Kirschner, M.B.; Williams, M.; Cheng, Y.Y.; Zandwijk, N.; Grusch, M.; Reid, G. A link between the fibroblast growth factor axis and the miR-16 family reveals potential new treatment combinations in mesothelioma. Mol. Oncol. 2017, 12, 58-73. [CrossRef]

62. Monaco, F.; Gaetani, S.; Alessandrini, F.; Tagliabracci, A.; Bracci, M.; Valentino, M.; Neuzil, J.; Amati, M.; Bovenzi, M.; Tomasetti, M.; et al. Exosomal transfer of miR-126 promotes the anti-tumour response in malignant mesothelioma: Role of miR-126 in cancer-stroma communication. Cancer Lett. 2019, 463, 27-36. [CrossRef]

63. Johnson, T.G.; Schelch, K.; Cheng, Y.Y.; Williams, M.; Sarun, K.H.; Kirschner, M.B.; Kao, S.; Linton, A.; Klebe, S.; McCaughan, B.C.; et al. Dysregulated Expression of the MicroRNA miR-137 and Its Target YBX1 Contribute to the Invasive Characteristics of Malignant Pleural Mesothelioma. J. Thorac. Oncol. 2018, 13, 258-272. [CrossRef]

64. Suzuki, R.; Amatya, V.J.; Kushitani, K.; Kai, Y.; Kambara, T.; Takeshima, Y. miR-182 and miR-183 Promote Cell Proliferation and Invasion by Targeting FOXO1 in Mesothelioma. Front. Oncol. 2018, 8, 446. [CrossRef]

65. Singh, A.; Pruett, N.; Pahwa, R.; Mahajan, A.P.; Schrump, D.S.; Hoang, C.D. MicroRNA-206 suppresses mesothelioma progression via the Ras signaling axis. Mol. Ther. Nucleic Acids 2021, 24, 669-681. [CrossRef]

66. Dulloo, S.; Bzura, A.; Fennell, D. Precision Therapy for Mesothelioma: Feasibility and New Opportunities. Cancers 2021, 13, 2347. [CrossRef] [PubMed] 